
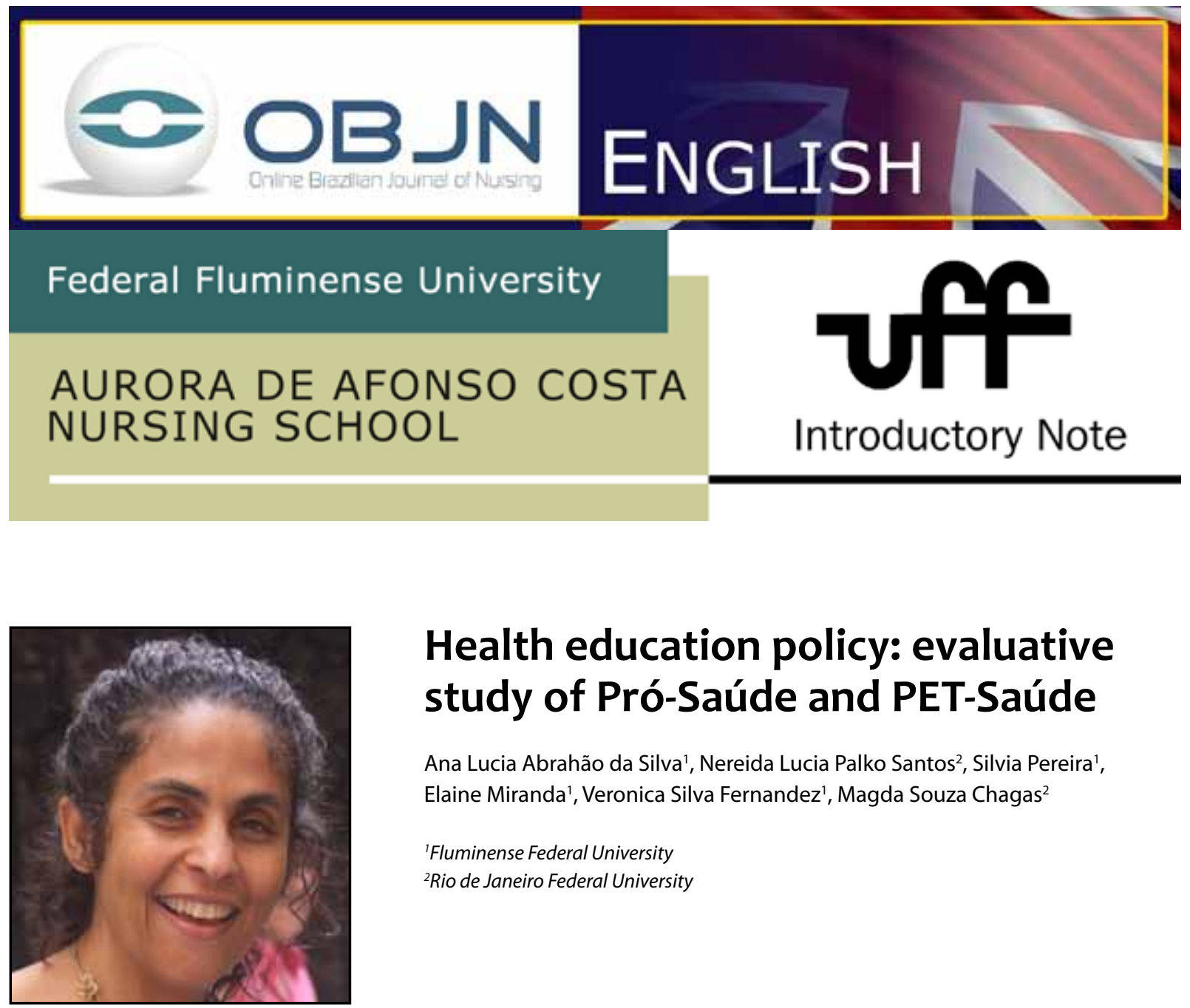

\title{
Health education policy: evaluative study of Pró-Saúde and PET-Saúde
}

\author{
Ana Lucia Abrahão da Silva', Nereida Lucia Palko Santos², Silvia Pereira', \\ Elaine Miranda', Veronica Silva Fernandez ${ }^{1}$, Magda Souza Chagas ${ }^{2}$ \\ 'Fluminense Federal University \\ ${ }^{2}$ Rio de Janeiro Federal University
}

\begin{abstract}
Aims: Evaluate the potentiality of Pró-Saúde and PET-Saúde proposals to provide an interdisciplinary and integral network education, from the micro policy of live work considering the complexity of the education/ service process, developed from tutorial groups. The proposals to be investigated are the ones related to Fluminense Federal University, Rio de Janeiro Federal University and Campinas State University.

Method: evaluative research, in which the data will be gathered through: documentation, simple observation, semi structured interview, focal group with actors from teaching institutions, managers, students, users and health care professionals; and crossed self-confrontation, within the period from December 2013 and August 2014. The data will be treated through the analysis of the speeches.

Results: Instrument of pedagogical practices in service evaluation with emphasis in the integrality of attention considering the local/regional context in which the research was done.

Descriptors: Teaching; Human Resources Formation; Patient-Centered Care; Health Policy.
\end{abstract}




\section{SITUATION PROBLEM AND ITS SIGNIFICANCE}

Since the late 1980s, the main areas producing national public policies point to the reformulation of health care professionals' education associated to the reorientation of the model based on promotional health care actions and disease prevention, in opposition to the hospital-centered care. In this context of national agenda, challenges in professionals' education field and health care teams' qualification are brought to attention. Several initiatives to overcome the challenges related to health care education can be observed, what become evident in the exact moment when the graduation schools are beginning their teaching activities in the context of Health Care Unified System (HCUS). One of these initiatives has been marked by the National Program for Reorientation of Health Care Education (Programa Nacional de Reorientação da Formação Profissional em Saúde - Pró-Saúde, in Portuguese) and Program Education through Work (Programa de Educação pelo Trabalho para a Saúde - PET-Saúde, in Portuguese) ${ }^{(1)}$. They are proposals which stimulate the changes in professionals' education and qualification, having work as the learning axis, besides widening and strengthening the education/ servicerelationship ${ }^{(2)}$. In the last years, the proposal added to the debate the possibility of building the attention network as the focus of programs'actions, setting a challenge in the construction of an education capable of responding to the real necessities of the population in an integral way. This study has as an issue the challenges set in the health care teams' education and qualification field.

\section{AIMS}

General: Evaluate the potentiality of Pró-Saúde and PET-Saúde to provide an interdis- ciplinary and integral network education, from the micro policy of live work, considering the complexity of education/service articulation process developed from tutorial groups.

Specifics: Analyze and evaluate the organizing designs of education/service articulation and their effects upon the basic care; Analyze and evaluate the organizing designs used in health care education and their effects upon the students' education.

\section{METHOD}

The proposal designed for this study combines itself with what Hartz ${ }^{(3)}$ defines as "evaluative research": an ex-post judgment, which confounds itself with the notion of general research as new knowledge production over a given reality - only that here directly centered on social intervention. Such definition of evaluation distinguishes from another, more based, and called by the author as "normative evaluation": the judgment on the result of criteria application and previously established rules. The evaluative research in the context of programs' implementation is followed by a political perspective and a technological ambition even greater: the articulation of theory - through the speech - with action. Without obstacles, the relationship of speech with action is simultaneously the object of knowledge and an intervention instrument. Data gathering techniques: documents, simple observation, semi structured interview, focal group with actors from educational institutions, managers, students, users and health care professionals; and crossed self-confrontation. The data will be gathered from December 2013 to August 2014. The proposals that will be investigated are related to Fluminense Federal University, Rio de Janeiro Federal University and Campina State 
University. Around 200 random participants are expected and will be selected according to the criteria: to participate in proposals implemented in cities with population over 50,000 inhabitants, with more than one professionalizing course and that present a relationship with the change in education curriculum; the effective participation in the proposal for more than 6 months; to be a manager, health care professional, professor or student. The proposals which not include health care area and with focus on the disciplinary education will be excluded. The data will be treated through speech analysis.

\section{EXPECTED RESULTS}

Instrument of pedagogical practices in service evaluation with emphasis in the integrality of attention considering the local/regional context in which the research was done; information on the educational practices centered on health education.

\section{REFERENCES}

1. Araújo AMPB, Abrahão AL. Analysis of training in the health area: a map of curricular changes in education. Online braz j nurs [Internet]. 2012 Oct [cited 2013 Sept 7];11(2):483-7. Available from: http://www.objnursing.uff.br/index. php/nursing/article/view/3858. http://dx.doi. org/10.5935/1676-4285.2012S016

2. Abrahão AL, Cordeiro BC, Marques D, Daher DV, Teixeira GHMC, Monteiro KA, et al. A pesquisa como dispositivo para o exercício no PET-Saúde UFF/FMS Niterói. Rio de Janeiro, Brazil. Rev bras educ méd [Internet]. 2011 Sept [cited 2013 Aug 31]; 35(3):435-40. Available from: http://www.scielo.br/scielo.php?script=sci_ arttext\&pid=S0100-55022011000300019\&lng= pt\&nrm=iso. http://dx.doi.org/10.1590/S010055022011000300019

3. Hartz ZMA. Avaliação em Saúde: dos modelos conceituais à prática na análise da implantação de programas. Rio de Janeiro: Fiocruz; 2000.

Project Data

Project related to Study and Research in Management and Labor in Health Care Center / CNPq and to the Project "Acting on Health Care Networks - the conception widened through the assistance and care of psycho-social attention, in non-transmissible chronic disease and birth and delivery, in Niteroi city: a proposal of education/service integration"approved by CEP HUAP/UFF 209.321.

Received: $31 / 08 / 2013$

Revised: 10/09/2013

Approved: 12/09/2013 